\title{
EVALUASI RISIKO PROYEK IMPLEMENTASI SISTEM ERP DI USAHA KECIL DAN MENENGAH
}

\author{
INDRA CAHYADI \\ Universitas Trunojoyo Madura \\ PO Box 2, Kamal, Jawa Timur \\ Surel: indra.cahyadi@live.vu.edu.au
}

\begin{abstract}
ABSTRAK
Sistem Enterprise Resource Planning (ERP system) telah banyak digunakan oleh berbagai perusahaan Fokus penelitian ini adalah pada penerapan sistem ERP di sektor Usaha Kecil dan Menengah di Indonesia. Penelitian ini bertujuan untuk mempelajari bagaimana UKM dapat mengelola risiko pelaksanaan proyek sistem ERP yang merupakan sebuah proyek rekayasa bisnis yang mahal dan berisiko tinggi. Penelitian ini menggunakan studi kasus pada dua UKM sebagai obyek penelitian. Metode Risk Analysis Method digunakan untuk mengidentifikasi risiko yang dianggap paling kritis dari proyek sistem di UKM tersebut. Selanjutnya, metode Characteristics Analysis Method digunakan untuk menyusun rekomendasi agar proyek sistem informasi dapat dikelola sesuai dengan risiko yang teridentifikasi.
\end{abstract}

Kata kunci: manajemen risiko, sistem ERP, usaha kecil dan menengah

\begin{abstract}
Enterprise Resource planning (ERP) implementations in the context of small medium size enterprises $(S M E s)$ in Indonesia is discussed in this paper. Because SMEs are vulnerable organisations with a shortage of resources, it is essential for SMEs to succesfully implement an ERP system and reduce the risks and costs of business process reengineering embedded in it. Based on the case studies this paper analyzes organizational risk factor in ERP project in two Indonesian SMEs. By using company-specific Risk Analysis Method and Characteristics Analysis Method, the recommendations of how to manage the risks in ERP projects have been given.
\end{abstract}

Key words: risk management, ERP system, small and medium enterprises

\section{PENDAHULUAN}

Sistem Enterprise Resource Planning (ERP) merupakan suatu sistem terpadu berbasis teknologi informasi yang mengintegrasikan semua informasi dan proses organisasi dalam sebuah wadah. Sistem ERP ini berperan penting bagi sebuah organisasi dan individuindividu yang terlibat didalamnya untuk dapat mengambil, menilai, meringkas, menafsirkan, mengumpulkan, menggunakan, dan menganalisis informasi yang ada di organisasi tersebut (Davenport, 1998). Sebuah sistem ERP dapat disebut berhasil diimplementasikan di sebuah organisasi, apabila semua fungsi dari organisasi tersebut dapat saling terhubung (Iskanius, 2009). Proyek ERP mencakup rangkaian rekayasa ulang terhadap proses bisnis dan pengembangan sistem perangkat lunak yang terkait satu sama lain. Sehingga, sistem ERP bukan hanya merupakan sebuah platform sistem teknologi informasi, namun lebih merujuk pada sebuah konsep bisnis yang berinteraksi langsung dengan inti manajemen operasional sebuah organisasi. Seluruh perangkat lunak dan perangkat keras yang ada pada sistem ERP hanyalah sarana yang akan digunakan untuk mengelola sumber daya yang ada di perusahaan secara menyeluruh (Wallace dan Kremzar, 2001). 
Saat ini, berbagai macam produk ERP yang didedikasikan untuk pasar Usaha Kecil dan Menengah (UKM) mudah ditemukan. Jenis sistem ERP untuk UKM ini merupakan versi khusus yang dikembangkan untuk UKM dengan fungsi yang memadai, serta biaya lisensi dan biaya implementasi yang relatif rendah (Koh dan Simpson, 2005). Tentunya, UKM dan perusahaan besar memiliki proses bisnis yang berbeda yang memengaruhi metode dan praktek mereka dalam memulai implementasi sistem ERP (Soja, 2006). Proyek implementasi sistem ERP yang kompleks dan menguras sumber daya organisasi akan memunculkan berbagai hambatan yang harus dihadapi oleh suatu organisasi (Wright dan Wright, 2002). Hambatan utama yang umum ditemui di UKM adalah keterbatasan anggaran dan sumber daya serta tingkat sensitivitas yang tinggi terhadap biaya. Oleh karena itu, ada banyak hal yang perlu dipertimbangkan oleh UKM sebelum mereka memutuskan untuk melakukan implementasi sistem ERP. UKM terutama harus mewaspadai jumlah pengeluaran berupa ongkos dan biaya tersembunyi selama siklus proyek ERP yang dapat meningkatkan biaya pelaksanaan keseluruhan secara drastis (Aloini dkk., 2007). Disini peran manajer proyek untuk mengenali dan mengelola risiko yang terlibat dalam proyek menjadi sangat penting. Namun, proses manajemen risiko dalam implementasi perangkat lunak justru seringkali diabaikan, karena banyak manajer proyek yang menganggap hal tersebut sebagai beban pekerjaan tambahan yang boros biaya (Kwak dan Stoddard, 2004).

Risiko adalah bagian dari proyek ERP dan prosedur manajemen risiko yang terencana secara sistematis dalam pelaksanaan proyek dapat mengurangi kemungkinan risiko yang terjadi. Haddara (2011) menyatakan bahwa tingkat keberhasilan implementasi sistem ERP di UKM dapat diperbaiki dengan mengenali sifat risiko proyek teknologi informasi, terutama faktor risiko dan kebutuhan strategis proyek, pengalaman kegagalan proyek pendahulu dan inovasi untuk memecahkan permasalahan dan hambatan. Risiko lebih tinggi untuk UKM berupa pembengkakan biaya selama pelaksanaan dapat meningkatkan beban keuangan perusahaan dan dengan demikian secara substansial memengaruhi kinerja perusahaan (Cereola, 2006). UKM membutuhkan waktu yang lebih lama untuk pulih apabila implementasi sistem ERP mengalami implementasi kegagalan, bila dibandingkan dengan upaya dari perusahaan besar (Muscatello dkk., 2003). Liang et al. (2007) menyatakan bahwa tingkat kegagalan proyek sistem ERP mencapai 40-60\%. Tingkat kegagalan yang tinggi tersebut juga mencakup proyek implementasi sistem ERP pada UKM di banyak negara berkembang. Oleh karena itu, dengan menggunakan studi kasus pada dua perusahaan, penelitian ini meneliti risiko yang dihadapi oleh UKM di Indonesia dalam upayanya untuk menerapkan sistem ERP dan tindakan apa yang dapat dilakukan untuk meminimalkan risiko kegagalan proyek tersebut.

\section{METODE}

Beberapa alat standar dan metode telah dikembangkan untuk membantu perusahaan mengelola proyek ERP mereka. Studi ini menggunakan metode Risk Analysis Method (RAM) dan metode Characteristics Analysis Method (CAM) untuk memahami pengelolaan risiko proyek sistem ERP di UKM. Metode RAM digunakan untuk mengidentifikasi dan menilai titik risiko kritis dari proyek ERP. Kemudian, metode CAM akan digunakan untuk menyusun perencanaan proyek ERP menjadi bagian-bagian tertentu sehingga risiko kegagalan proyek secara keseluruhan dapat diminimalisir. Penelitian yang dilakukan merupakan studi kasus pada dua UKM yang hendak menerapkan sistem ERP. Responden dari penelitian ini adalah karyawan dari berbagai tingkatan dan departemen dimana proyek sistem ERP nanti digunakan.

Analisis dengan metode RAM mengidentifikasi hal-hal yang dianggap paling berisiko dan dampak risiko tersebut terhadap perusahaan. Daftar risiko yang digunakan dalam studi ini disusun berdasarkan 63 pertanyaan dan pernyataan yang berhubungan dengan seleksi, implementasi, dan 
Tabel 1. Contoh Pertanyaan untuk Menganalisis Resiko dengan Metode RAM

\begin{tabular}{ll}
\hline \multicolumn{1}{c}{ Tipe Risiko } & \multicolumn{1}{c}{ Obyek Risiko } \\
\hline & Perancangan proses bisnis \\
Kegagalan & Integrasi data pada departemen yang terkait \\
dalam.... & Kerjasama antara anggota tim dari perusahaan dan konsultan \\
& Mencapai standar operasi yang sesuai dengan sistem \\
& Mendisiplinkan karyawan untuk memdokumentasikan setiap aktivitas \\
\hline
\end{tabular}

penggunaan sistem ERP (Vilpola, 2008). Tabel 1 merupakan contoh pertanyaan atau pernyataan yang digunakan pada penelitian ini.

Tujuan dari metode RAM adalah untuk mengidentifikasi risiko yang mungkin timbul saat pelaksanaan proyek ERP dengan cara melibatkan dan mewawancarai karyawan perusahaan dari berbagai tingkatan. Karyawan-karyawan tersebut sebagai responden diminta untuk menilai risiko proyek ERP dengan mengevaluasi probabilitas dan dampak masing-masing risiko dalam skala satu sampai lima. Nomor 1 berarti kemungkinan dan dampaknya bagi perusahaan yang sangat kecil, dan nomor 5 berarti risiko tersebut memiliki probabilitas tinggi dan dapat menimbulkan bencana. Selanjutnya, tingkat signifikansi setiap risiko didapatkan dengan mengalikan nilai probabilitas, 1 sampai 5 , dengan nilai efek, 1 sampai 5 , sehingga akan didapat rentang nilai di antara 1-25 (Vilpola, 2008).

Analisis dengan metode CAM adalah metode untuk memastikan bahwa proyek sistem informasi dikelola sesuai dengan konten dan tujuan pengembangan sistem tersebut. Hasil CAM adalah rekomendasi untuk membagi proyek sistem informasi yang kompleks dalam beberapa proyek kecil (Forselius, 2008). Dalam penelitian ini, analisis CAM terbentuk dari 90 pertanyaan yang berhubungan dengan proyek sistem informasi. Tujuan dasarnya adalah untuk mengetahui skala proyek ERP yang akan diterapkan dalam perusahaan. Berdasarkan metode CAM selanjutnya akan diperoleh rekomendasi dimana pihak manajemen harus menaruh perhatian lebih agar proyek sistem ERP di perusahaan tersebut dapat berhasil. Responden kemudian mengisi kuesioner yang berisikan pertanyaan-pertanyaan dalam metode CAM berupa pernyataan positif atau negatif yang mengevaluasi sejauh mana aspek manajemen telah diterapkan pada proyek sistem ERP $(0=$ tidak benar, $5=$ tepat, $\mathrm{N} / \mathrm{A}=$ tidak tahu). Hasil metode ini selanjutnya diolah dengan fasilitas tabulasi MS Excel dan digambarkan secara grafis (Forselius, 2008).

\section{HASIL DAN PEMBAHASAN}

\section{Identifikasi Risiko dalam Proyek Sistem ERP UKM Y}

UKM Y adalah pemasok dan produsen heat transfer device yang terletak di Surabaya. Perusahaan ini didirikan pada tahun 2010 yang utamanya bergerak di jasa konstruksi yang berspesialisasi di bidang kilang pengolahan gas dan industri petrokimia. Seiring tumbuhnya persaingan dari perusahaan sejenis, UKM Y memutuskan untuk meningkatkan efisiensi bisnis mereka dalam segala bidang melalui proses komputerisasi. Secara spesifik UKM Y membutuhkan sebuah sistem yang mampu memberikan breakdown anggaran dan informasi secara lengkap yang akan digunakan dalam pengajuan proposal sebuah proyek, sehingga perusahaan memutuskan untuk menerapkan sebuah sistem ERP yang komprehensif.

Proses bisnis di UKM Y melibatkan berbagai bagian untuk mempersiapkan dokumendokumen seperti: purchase request, purchase order, sales order, inventory handling and control, material requirement planning (MRP), bill of material (BOM), dan work order. Bagian produksi dan akutansi saat ini menggunakan bantuan spreadsheet Excel dan database Access 
untuk menjaga konsistensi dan keseragaman informasi dengan software akuntansi yang sudah ada. Pemilik UKM Y mengakui bahwa cara double entry tersebut sangat membuang waktu dan membuat perusahaan tidak bisa bersaing dengan perusahaan lain terutama bila calon klien menginginkan perhitungan anggaran dan proposal proyek dalam waktu singkat. Mengingat fakta bahwa software yang ada tidak mampu memenuhi kebutuhan perusahaan, pemilik UKM $\mathrm{Y}$ berusaha menemukan solusi yang lebih baik dan kemudian mendapati demo sistem ERP yang tampaknya dapat memenuhi kebutuhan bisnis dan memberikan manfaat yang besar bagi UKM tersebut.

Meski demikian, pemilik UKM Y berhatihati dan merasa perlu mempelajari proses bisnis sistem baru ini. Pemilik UKM Y juga merasa bahwa biaya proyek sistem ERP yang diusulkan perlu disesuaikan dengan anggaran yang telah ditetapkan oleh perusahaan. Sebagai mantan direktur di sebuah perusahaan manufaktur besar, pemilik UKM Y ingin menghindari proses modifikasi atau kustomisasi sistem ERP yang dapat meningkatkan biaya implementasi atau menimbulkan biaya pemeliharaan yang terus menerus. Dengan metode RAM, pemilik dan karyawan yang terkait dengan proyek sistem ERP mengisi dan menilai kemungkinan serta dampak risiko dari proyek tersebut. Dengan mengambil rata-rata dari masing-masing item pertanyaan pada kuesioner, diperoleh faktor-faktor yang dianggap paling berisiko untuk menyebabkan kegagalan. Dengan rentang nilai di antara 1-25, maka semakin besar nilai sebuah faktor, semakin tinggi risiko kegagalan proyek yang disebabkan oleh faktor tersebut.

Pada tahap seleksi ERP, faktor-faktor yang dianggap paling berisiko adalah: kesalahan dalam memilih vendor dan sistem ERP (16), kesalahan dalam memilih manajer proyek (16), kesalahpahaman dalam pembuatan kontrak kerja (12), ketidakmampuan sistem ERP untuk menjalankan proses bisnis perusahaan (12), dan kebutuhan khusus dari perusahaan tidak didefinisikan (10). Pada tahap implementasi sistem ERP, hal yang dianggap paling berisiko adalah: karyawan tidak memiliki pengetahuan tentang ERP yang memadai (20), ketidakdisiplinan karyawan untuk melakukan data entry secara akurat (16), tidak ada dukungan dari karyawan selama pelaksanaan proyek (16), dan ketidakmampuan tim proyek untuk mengimplemetasikan sistem ERP secara benar (15). Pada tahap penggunaan ERP, hal-hal yang dianggap memiliki risiko paling tinggi adalah: sistem kegagalan sistem ERP untuk mendukung proses bisnis perusahaan (12), kegagalan sistem

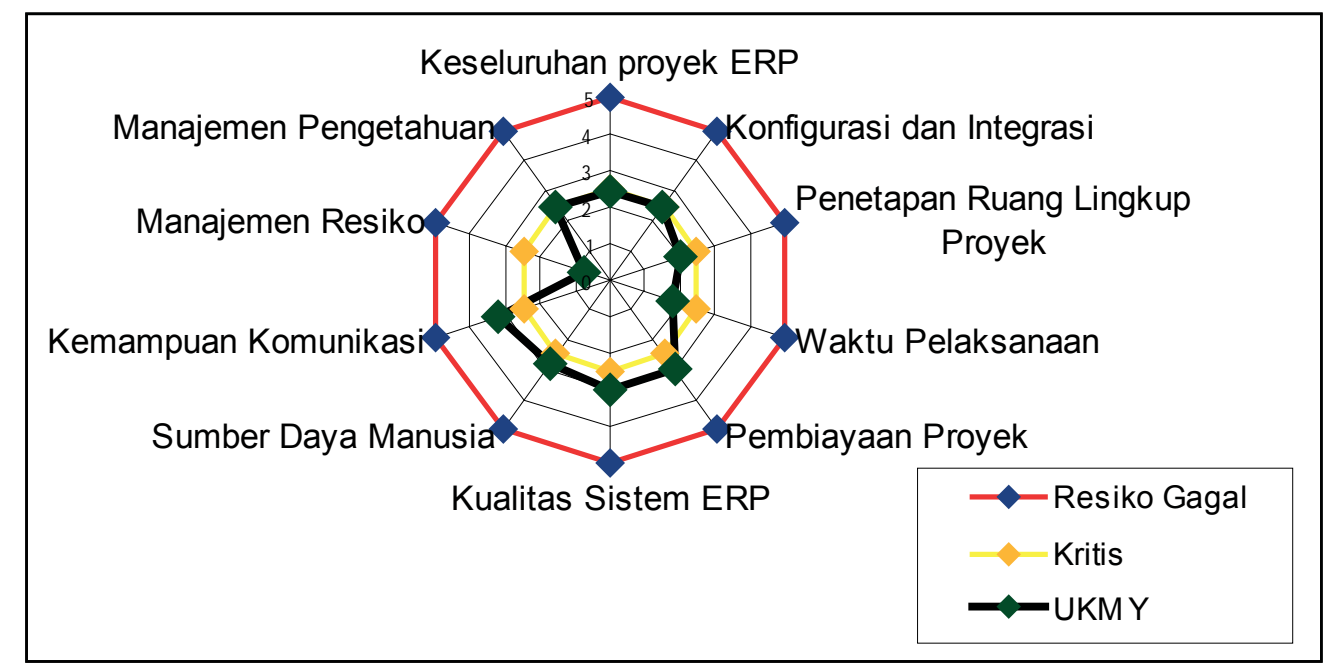

Gambar 1. Diagram CAM Perusahaan UKM Y 
ERP untuk menyediakan informasi yang tepat bagi perusahaan (12), ketidakdisiplinan karyawan untuk mengoperasikan sistem secara rutin (12), dan penggunaan sebagian sistem ERP yang terbatas di departemen tertentu saja (10).

Dengan metode CAM (Gambar 1), hanya waktu pelaksanaan, penetapan ruang lingkup proyek, dan pengelolaan risiko yang dianggap tidak akan menyebabkan kegagalan proyek sistem ERP di UKM Y. Sedangkan aspek lain yakni konfigurasi dan integrasi, pembiayaan proyek, kualitas sistem erp, sumber daya manusia, kemampuan komunikasi dan manajemen pengetahuan dipandang sebagai hal-hal kritis yang perlu diperhatikan selama pelaksanaan proyek ERP.

\section{Identifikasi Risiko Dalam Proyek Sistem ERP UKM Z}

UKM Z adalah perusahaan kelas menengah yang bergerak di bidang manufaktur furniture dan berlokasi di daerah industri Pasuruan. UKM Z membuat keputusan untuk fokus pada ekspor dan mencari peluang untuk pertumbuhan di pasar mebel yang makin berkembang di luar negeri. UKM Z memutuskan untuk menerapkan sistem ERP untuk mendukung ekspansi bisnis dan meningkatkan proses produksi mereka dengan memanfaatkan dukungan Teknologi Informasi (TI).

Ide membawa perubahan dalam proses bisnis telah menjadi titik fokus di sebagian besar pertemuan manajerial di UKM Z selama beberapa tahun, namun belum pernah direalisasikan. Sejak terjadinya peningkatan permintaan dan beragamnya model mebel yang perlu diproduksi, pemilik menyadari bahwa optimasi proses dan penerapan sistem komputer yang terintegrasi sangat diperlukan untuk mendukung perkembangan perusahaan. Pada awalnya, UKM $\mathrm{Z}$ menerapkan berbagai perangkat lunak standar, terutama di bidang keuangan, akuntansi dan pergudangan, tetapi mereka tidak terintegrasi ke dalam suatu sistem terpadu. Pemilik merasakan urgensi untuk menerapkan sistem yang terintegrasi yang dapat memberikan koordinasi yang lebih baik antara bagian dan meningkatkan efisiensi proses di perusahaan tersebut.

Kelemahan yang siginifikan di UKM Z adalah belum diterapkannya sistem komputer yang handal pada bagian produksi. Akibatnya, terlalu banyak dokumen yang beredar di lantai produksi, lembaran pekerjaan, material sering hilang, dan susah dilacak. Akibatnya, arus informasi di lantai produksi menjadi susah dikendalikan dan dilacak. Hal ini mendorong pemilik UKM Z untuk menerapkan sistem ERP untuk meningkatkan efisiensi proses bisnis dan merekayasa kembali pengelolaan lantai produksi yang ada. Dengan metode RAM, pemilik dan karyawan UKM Z melakukan hal yang sama dengan apa yang dilakukan oleh pemilik dan karyawan UKM Y. Pemilik dan karyawan yang terkait dengan proyek sistem ERP mengisi dan menilai nilai kemungkinan serta dampak risiko dari proyek tersebut. Dengan mengambil ratarata dari masing-masing item pertanyaan pada kuesioner, diperoleh faktor-faktor yang dianggap paling berisiko untuk menyebabkan kegagalan. Dengan rentang nilai di antara 1-25, maka semakin besar nilai sebuah faktor, semakin tinggi risiko kegagalan proyek yang disebabkan oleh faktor tersebut.

Pada tahap seleksi ERP, risiko yang paling dianggap penting diperhatikan dalam realisasi proyek adalah: kontrak perjanjian yang merugikan perusahaan (16), kebutuhan khusus perusahaan tidak mampu didefinisikan dalam sistem ERP (16), pemilihan vendor dan sistem ERP yang tidak tepat (12), dan ketidakmampuan sistem mengikuti perkembangan bisnis perusahaan (12). Pada tahap Implementasi ERP, risiko yang paling penting adalah: karyawan tidak berkomitmen untuk menjalankan sistem ERP (20), karyawan tidak memiliki pengetahuan tentang ERP yang memadai (20), proyek sistem ERP mengganggu proses bisnis yang sudah ada (16), tidak ada dukungan dari karyawan selama pelaksanaan proyek (16), sistem ERP tidak berfungsi karena konfigurasi dan kustomisasi perangkat lunak yang tidak tepat (16), dan ketidakdisiplinan karyawan untuk melakukan data entry secara 


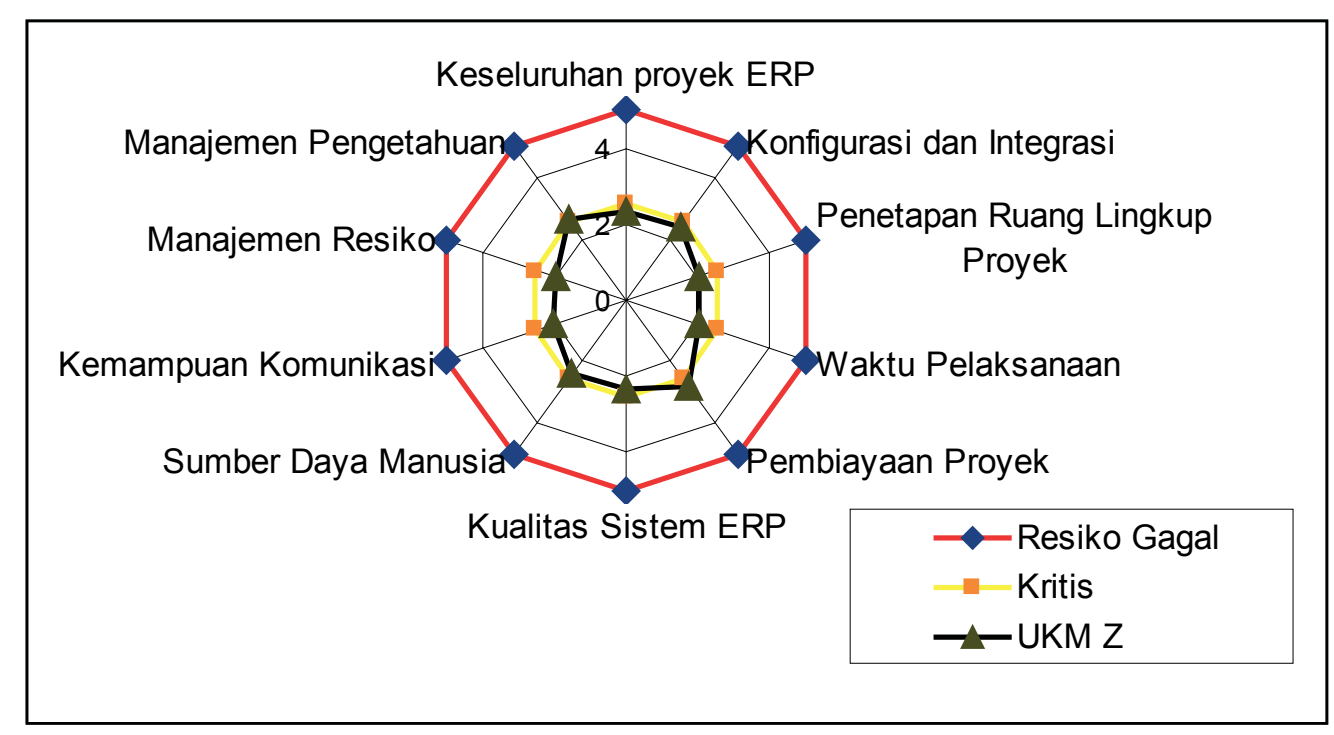

Gambar 2. Diagram CAM Perusahaan UKM Z

akurat. Pada tahap Penggunaan ERP, risiko yang paling penting adalah: ketidakdisiplinan penggunaan sistem ERP (12), sistem ERP tidak sesuai dengan proses bisnis perusahaan (12), dan hanya sebagian dari sistem yang digunakan dan dirasakan manfaatnya bagi perusahaan (12).

Menurut metode CAM (Gambar 2), manajemen pengetahuan dan pembiayaan proyek adalah aspek yang melebihi tingkat kritis. UKM $\mathrm{Z}$ harus memberikan perhatian khusus pada kedua aspek tersebut dalam manajemen proyek ERP mereka. Selain itu, beberapa aspek lainnya, seperti kemampuan komunikasi, konfiguras dan integrasi, kualitas sistem ERP, dan sumber daya manusia berada nyaris tepat di tingkat kritis. hanya penetapan ruang lingkup proyek, waktu pelaksanaan, dan manajemen risiko yang berada di bawah tingkat kritis. Sehingga dapat dilihat bahwa faktor-faktor yang berhubungan dengan pelatihan karyawan untuk meningkatkan keterampilan dan pengetahuan dianggap sebagai hal yang perlu diperhatikan dalam proyek ERP di UKM Z, sesuai dengan faktor-faktor risiko yang dianggap paling potensial menurut RAM.

\section{Rekomendasi Untuk Mengurangi Risiko Kegagalan Proyek ERP}

Proyek sistem ERP semestinya tidak dilihat hanya sebagai sebuah proyek untuk memasang dan menggunakan sistem teknologi informasi baru namun harus dilihat sebagai sebuah proyek untuk mengembangkan proses bisnis perusahaan dalam kerangka kerja yang terkomputerisasi. Beberapa pendekatan dapat diambil dalam pelaksanaan proyek ERP. Pertama, perusahaan dapat mengubah proses bisnis agar sesuai dengan alur logika dalam perangkat lunak yang hendak digunakan. Dengan demikian, perusahaan modifikasi dan kustomisasi pada aplikasi dapat ditekan seminimal mungkin. Hal ini akan mengakibatkan berubahnya tata cara kerja yang selama ini ada di perusahaan yang selama ini dianggap tidak memberikan keunggulan kompetitif. Kedua, melakukan modifikasi software agar aplikasi yang ada sesuai dengan proses bisnis perusahaan. Pilihan ini akan memperlambat proyek, karena akan memengaruhi stabilitas dan struktur pemrograman dari aplikasi perangkat tersebut. Sistem ERP tersebut selanjutnya akan 
sulit untuk diperbarui ke versi yang lebih baru karena kustomisasi yang dibuat biasanya telah merubah dan menulis ulang program pada versi aplikasi sebelumnya. Sebaliknya, hal ini berarti perubahan organisasi tidak banyak terjadi, karena sistem ERP yang dipasang tidak memerlukan perubahan praktik bisnis yang drastis dan tidak mengubah tata cara orang bekerja di perusahaan tersebut.

Perusahaan UKM biasanya memiliki masalah yang besar dalam proyek sistem ERP mereka. Risiko yang paling umum ditemui dalam setiap kegagalan proyek adalah kurangnya sumber daya dan kemampuan TI dari karyawan perusahaan. Sistem ERP biasanya dirancang untuk perusahaan besar, dan vendor ERP belum tentu memahami karakteristik khusus dan proses operasional perusahaan kecil. Keberhasilan suatu proyek ERP juga sangat tergantung pada seberapa baik UKM dapat mengelola perubahan dalam bisnis mereka dan seberapa baik karyawan dapat mengadopsi tata cara kerja yang baru. Proses perubahan ini sebaiknya sudah dimulai dalam tahap awal proyek ERP, karena banyak risiko dapat dihilangkan sebelum sistem proyek ERP dimulai. UKM dapat mempekerjakan karyawan lain untuk melakukan operasi rutin sehingga karyawan yang terlibat dalam tim proyek ERP memiliki lebih banyak waktu untuk berkonsentrasi pada karakteristik sistem ERP dan mempelajari tata cara kerja yang baru.

Dari kedua studi kasus di atas dapat dilihat bahwa risiko yang berpotensi menyebabkan kegagalan terkait dengan vendor ERP. Perusahaan dapat terjebak dalam memilih vendor ERP yang tidak mengerti kebutuhan khusus perusahaan, atau tidak memiliki komitmen untuk melakukan proyek ERP pada perusahaan kecil. Potensi risiko lainnya adalah bila vendor ERP tersebut memilih untuk menghentikan pengembangan dan/atau dukungan teknis pada sistem ERP yang mereka pasang. Padahal, hasil proyek sistem ERP sangat tergantung pada kinerja, fitur teknis, dan fungsional sistem; dalam hal ini seberapa jauh sistem dapat diimplementasikan, dikonfigurasi, dikalibrasi, dan terintegrasi dengan proses bisnis perusahaan.

Selain itu, sebagian potensi risiko juga terkait dengan manajemen UKM sendiri, seperti keterampilan, pengetahuan, dan pengalaman karyawan. Sikap resistensi terhadap perubahan adalah faktor risiko yang potensial. Karyawan mungkin tidak mampu melihat manfaat dari sistem dalam pekerjaan dengan demikian tidak berkomitmen untuk menjalankan model bisnis baru serta menggunakan sistem ERP secara disiplin. Karyawan juga dapat bersikap enggan untuk terlibat dalam proses pengembangan sistem ERP karena mereka masih harus melakukan kegiatan bisnis sehari-hari secara normal. Oleh karena itu, dukungan dari manajemen puncak dan pemilihan tim proyek ERP yang tepat merupakan faktor keberhasilan yang paling penting untuk proyek ERP pada kedua studi kasus tersebut.

Menurut CAM, investasi terbesar dalam proyek ERP harus diarahkan pada manajemen sumber daya manusia dan manajemen pengetahuan. Tantangan terbesar dalam proses sistem ERP adalah untuk membuat karyawan bersedia melakukan perubahan. Untuk itu, komitmen dari seluruh karyawan perusahaan harus kuat agar proses bisnis yang dikembangkan dapat segera diterapkan dan sistem ERP dapat dimanfaatkan secara maksimal. Umumnya, karyawan akan menggunakan berbagai alasan untuk menjelaskan mengapa proses kerja yang ada tidak perlu dirubah atau mengapa lebih baik untuk tetap menggunakan cara lama dalam melakukan sesuatu, padahal mereka tidak sepenuhnya memahami tujuan perubahan. Untuk itu, pemilik UKM dan tim proyek ERP perlu menciptakan visi yang jelas dari perubahan yang diinginkan dan aktif berkomunikasi kepada orang-orang yang terkait dan terdampak dengan adanya perubahan tersebut. Usaha untuk meningkatkan komitmen karyawan terhadap proses dan proses bisnis baru dapat dicapai dengan terus menerus mengkomunikasikan perubahan dan memberikan pelatihan pada karyawan. 
Pentingnya komunikasi juga dapat dilihat dari kenyataan bahwa komunikasi meningkatkan komitmen pihak manajemen dalam proyek sistem ERP. Potensi kesalahpahaman dan pengendalian ekspektasi yang muncul dari karyawan dapat ditekan melalui penyusunan rencana komunikasi di mana kelompok sasaran, sarana, dan waktu komunikasi diuraikan secara terarah.

Dari aspek manajemen pengetahuan, tim proyek ERP harus mempersiapkan dan memilih konten pengetahuan yang disediakan di sekitar perusahaan. Risiko kegagalan proyek ERP dapat ditekan apabila pengetahuan yang tersedia dengan mudah dipahami dan diakses oleh pengguna yang dituju dan karyawan terkait lainnya. Dalam memenuhi kepuasan berbagai pengguna, tim proyek ERP harus menyeimbangkan konten pengetahuan yang disajikan untuk karyawan kunci dan karyawan biasa yang berada di luar tim proyek. Bagi karyawan yang berada di luar tim, muatan pengetahuan harus disajikan dalam bahasa yang mudah dimengerti dan memungkinkan pengguna awam untuk memahaminya. UKM dapat melakukan hal ini melalui kerja sama dengan konsultan yang memiliki basis pengetahuan dan studi kasus terbaru dari perusahaan sejenis.

\section{SIMPULAN}

Penelitian ini menyajikan pengamatan dan studi kasus terhadap dua UKM untuk mendapatkan analisis risiko dan analisis karakteristik kedua UKM tersebut dalam pelaksanaan proyek sistem ERP. Metode RAM dan CAM yang digunakan dalam studi kasus ini menampilkan potensi risiko yang mungkin terjadi pada berbagai tahap proyek ERP. Karena pelaku usaha UKM sangat bergantung pada permodalan dan kondisi finansial yang sehat, proyek implementasi ERP yang gagal akan mengakibatkan pengeluaran yang tidak terkendali dan sangat merugikan. Dari sudut pandang praktis, memahami faktor-faktor penentu risiko implementasi ERP akan membantu UKM untuk menghindari munculnya biayabiaya tambahan selama proyek berlangsung.
Oleh karena itu, rencana bisnis yang jelas dan visi untuk mengarahkan proyek diperlukan selama pelaksanaan proyek ERP. Hasil penelitian ini menunjukkan bahwa pengelolaan sumber daya manusia, alih pengetahuan, komunikasi dan komitmen manajemen untuk menjelaskan dampak strategis proyek sistem ERP bagi UKM adalah sangat penting. Hal ini akan membantu UKM untuk mengurangi risiko kegagalan proyek ERP dan selanjutnya dapat mengembangkan proses bisnis dan produk yang berdaya saing tinggi dan menguntungkan.

\section{DAFTAR PUSTAKA}

Aloini, D., Dulmin R., and Mininno V., 2007. Risk Management in ERP Project Introduction: Review of a Literature, Information \& Management, 44, 547-567.

Cereola, S.J. 2006. The Performance Effects of Latent Factors on Assimilation of Commercial Open-Source ERP Software on Small-Medium Enterprises, PhD thesis, Virginia Commonwealth University, Richmond, Virginia.

Davenport, T.H., 1998. Putting the Enterprise into The Enterprise System, Harvard Business Review, 76 (4), 121-131.

Forselius, P., 2008. Software Development Program Characteristics, http://citeseerx.ist.psu.edu/ viewdoc/summary?doi=10.1.1.131.1516, diakses pada tanggal 20 Februari 2015.

Haddara, M., 2011. ERP Adoption Cost Factors in SMES, Proceeding on European, Mediterranean \& Middle Eastern Conference on Information Systems.

Iskanius, P., 2009, The ERP Project Risk Assessment, Proceedings of the World Congress on Engineering.

Koh, S.C.L. dan Simpson, M., 2005. Change and Uncertainty in SME Manufacturing Environments using ERP, Journal of Manufacturing Technology Management, 16 (6), 629-653.

Kwak, Y.H. dan J. Stoddard, 2004. Project Risk Management: Lessons Learned from Software Development Environment, Technovation, 24 (11)

Liang, H., Saraf, N., Hu, Q. and Xue, Y., 2007. Assimilation of Enterprise Systems: The Effect of Institutional Pressures and the Mediating Role of Top Management, MIS Quarterly, 31, 59-87.

Muscatello, J., Small M., and Chen, I., 2003. Implementing Enterprise Resource Planning (ERP) Systems in Small and Midsize Manufacturing Firms, International Journal 
of Operations and Production Management, 23 (7/8), 850-871.

Soja, P., 2006. Success Factors in ERP Systems Implementations: Lessons from Practice, Journal of Enterprise Information Management, 19(4), 418-433.

Vilpola, I., 2008. Applying Use-centered Design in ERP Implementation Requirements Analysis, Tampere University of Technology, Publication 739, Tampere.
Wallace, T.F., dan Kremzar, M.H., 2001. ERP: Making It Happen The Implementers' Guide to Success with Enterprise Resource Planning, 1st ed., New York: John Wiley and Sons.

Wright, S. dan Wright A.M., 2002. Information System Assurance for Enterprise Resource Planning Systems: Unique Risk Considerations, Journal of Information Systems, 16, 99-113. 